\title{
New Isomeric Azine-Bridged Dinuclear Platinum(II) Complexes Circumvent Cross-Resistance to Cisplatin
}

\author{
Seiji Komeda, ${ }^{\dagger}$ Ganna V. Kalayda, ${ }^{\dagger}$ Martin Lutz, ${ }^{\ddagger}$ Anthony L. Spek, ${ }^{\ddagger}$ Yasuyuki Yamanaka, ${ }^{\S}$ Takaji Sato, \\ Masahiko Chikuma, $\$$ and J an Reedijk*,† \\ Leiden Institute of Chemistry, Gorlaeus Laboratories, Leiden University, P.O. Box 9502, 2300 RA Leiden, The Netherlands, \\ Department of Crystal and Structural Chemistry, Bijvoet Center for Biomolecular Research, Utrecht University, Padualaan 8, \\ 3584 CH Utrecht, The Netherlands, and Osaka University of Pharmaceutical Sciences, 4-20-1 Nasahara, \\ Takatsuki, 569-1094, J apan
}

Received J anuary 2, 2002

Four new isomeric azine-bridged complexes ([\{cis-Pt $\left.\left.\left(\mathrm{NH}_{3}\right)_{2} \mathrm{Cl}\right\}_{2}(\mu-\mathrm{pzn})\right] \mathrm{Cl}_{2}(\mathbf{l a})(\mathrm{pzn}=$ pyrazine)

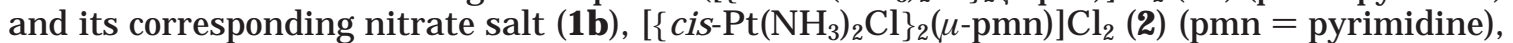
and $\left[\left\{\text { cis-Pt }\left(\mathrm{NH}_{3}\right)_{2} \mathrm{Cl}\right\}_{2}(\mu-\mathrm{pdn})\right]\left(\mathrm{NO}_{3}\right)_{2}$ (3) (pdn = pyridazine) have been newly synthesized as potential anticancer compounds. These complexes have been characterized by ${ }^{1} \mathrm{H}$ and ${ }^{195} \mathrm{Pt}$ NMR spectroscopy, and also the X-ray crystal structure of $\mathbf{1 b}$ has been determined. The reactions of $\mathbf{1 a}, \mathbf{2}$, and $\mathbf{3}$ with guanosine-5'-monophosphate (GMP) have been monitored and kinetically investigated in $\mathrm{D}_{2} \mathrm{O}$ solutions at $310 \mathrm{~K}$ using ${ }^{1} \mathrm{H}$ NMR spectroscopy. Both $\mathbf{1 a}$ and $\mathbf{2}$ react with 2 equiv of GMP to form 1:2 complexes. The reactions involve a stepwise direct substitution of chloride ligands by GMP, with similar reaction rates for both complexes. On the other hand, the reaction of $\mathbf{3}$ with GMP results in the cleavage of one of the Pt-N (pyridazine) bonds to form an N7,06-platinated polymer. The reaction products have been separated and have been characterized by ${ }^{1} \mathrm{H}$ and ${ }^{195} \mathrm{Pt}$ NMR spectroscopy. A cytotoxicity assay of the azine bridged complexes (1a, $\mathbf{1 b}, \mathbf{2}$, and $\mathbf{3}$ ) has been performed on human tumor cell lines and two L1210 murine leukemia cell lines (one sensitive to and one resistant to cisplatin). In general, the complexes show lower cytotoxicity than cisplatin for the human tumor cell lines except for the IGROV cell line. Their cytotoxicity for the mouse cell lines is comparable to or higher than that of cisplatin. Furthermore, these complexes appeared to largely or partly overcome the cross-resistance to cisplatin. I mplications of these findings are discussed in the context of a structure-activity relationship for this class of compounds.

\section{Introduction}

cis-Diamminedichloroplatinum(II) (cisplatin), a squareplanar platinum(II) complex, is one of the most widely used anticancer drugs ${ }^{1,2}$ and highly effective in the treatment of testicular and ovarian cancer. ${ }^{3}$ However, some drawbacks in the dinic still remain such as serious nephrotoxicity ${ }^{4}$ and drug resistance. ${ }^{5}$ The resistance can be intrinsic or acquired, and the former limits the applicability of cisplatin to a relatively narrow range of tumors. The latter turns up after repeated administrations and limits the chemotherapy.

The ultimate target of cisplatin in cancer cells has been generally believed to be the DNA, ${ }^{6}$ in which the platinum complex generates 1,2-intrastrand cross-links inducing a severe kink of DNA. ${ }^{7-11}$ The resulting local conformational changes of DNA generated by platinum complexes might determine the antitumor activity of cisplatin. The mechanism of cisplatin-resistance seems to be multifactorial, and decreased drug accumulation, ${ }^{12-15}$ increased intracellular detoxification, ${ }^{16-20}$ and enhanced DNA repair ${ }^{21}$ are known as three main factors. Assuming that the enhanced DNA repair is present as a certain mechanism of the drug resistance,

* Corresponding author. Phone +31715274459, Fax: +31715274671, e-mail: reedijk@chem.leidenuniv.NL.

† Leiden University.

‡ Utrecht University.

$\S$ Osaka University of Pharmaceutical Sciences. a rational approach is to design a platinum compound that would bind to DNA in a different manner.

Some of us reported that the azole-bridged dinuclear platinum(II ) complexes, [ $\left.\left\{\text { cis- } \mathrm{Pt}\left(\mathrm{NH}_{3}\right)_{2}\right\}_{2}(\mu-\mathrm{OH})(\mu-\mathrm{pz})\right]-$ $\left(\mathrm{NO}_{3}\right)_{2}(\mathrm{pz}=$ pyrazolate $)$ and $\left[\text { cis-Pt }\left(\mathrm{NH}_{3}\right)_{2}\right\}_{2}(\mu-\mathrm{OH})(\mu-$ 1,2,3-ta-N1,N2)] $\left(\mathrm{NO}_{3}\right)_{2}$, (1,2,3-ta = 1,2,3-triazolate), are highly effective in vitro in a cisplatin-resistant cell line, as well as in several human tumor cell lines. ${ }^{22,23}$ As a main structural feature the azole-bridged complexes possess the leaving hydroxo group, an appropriate Pt. .Pt distance, and some flexibility to provide the 1,2intrastrand cross-links with a minimal distortion of the DNA. Recently, a subsequent study revealed that [ \{cis$\left.\left.\mathrm{Pt}\left(\mathrm{NH}_{3}\right)_{2}\right\}_{2}(\mu-\mathrm{OH})(\mu-\mathrm{pz})\right]\left(\mathrm{NO}_{3}\right)_{2}$ does provide 1,2-intrastrand d(GpG) cross-links with less local distortions than cisplatin and its mononuclear analogues. ${ }^{23-25}$ The reaction of [ $\left.\left\{\text { cis-Pt }\left(\mathrm{NH}_{3}\right)_{2}\right\}_{2}(\mu-\mathrm{OH})(\mu-1,2,3-t a-\mathrm{N} 1, \mathrm{~N} 2)\right]-$ $\left(\mathrm{NO}_{3}\right)_{2}$ and $\left[\left\{\mathrm{cis}-\mathrm{Pt}\left(\mathrm{NH}_{3}\right)_{2}\right\}_{2}(\mu-\mathrm{OH})(\mu-4-\right.$ phe-1,2,3-ta$\mathrm{N} 1, \mathrm{~N} 2)]\left(\mathrm{NO}_{3}\right)_{2}$ with a nucleobase and a nucleic acid, however, involves a novel isomerization, in which the Pt atom, initially bound to N2 on the 1,2,3-ta, migrates to N3 after the first substitution by N7 of a guanine base. ${ }^{23}$ With this latent isomerization ability these 1,2,3ta-bridged complexes will be capable of providing several types of different cross-links, such as 1,3- and 1,4intrastrand cross-links. This diversification of Pt-DNA adduct formation might also result in their high cytotoxicity. 
Scheme 1. Synthetic Scheme for the Azine-Bridged Dinuclear Platinum(II) Complexes

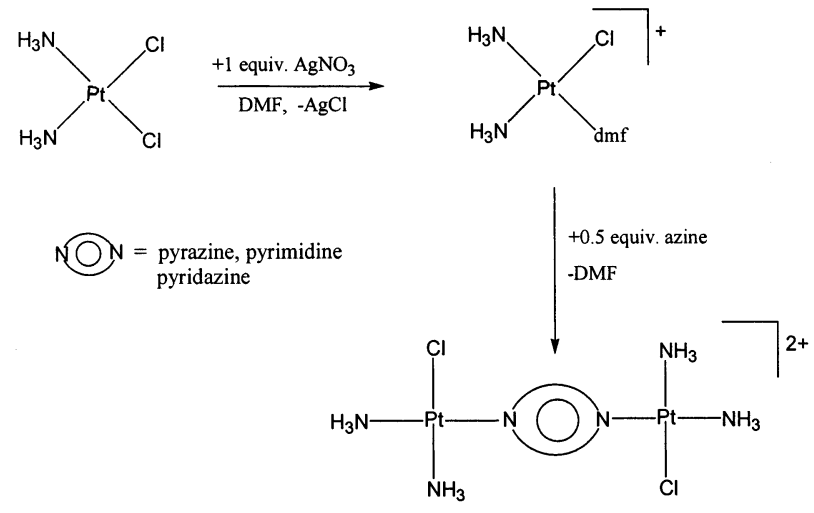

Therefore, we have applied isomeric azines (pyrazine (pzn), pyrimidine (pmn), and pyridazine (pdn)) as bridging ligands, for the synthesis of a new class of dinuclear platinum(II) complexes. Accordingly, the purpose of this project is to investigate the relationship between the Pt. ..Pt distance of the dinuclear platinum complexes and their antitumor properties. So, the dinuclear platinum(II) complexes with a variable Pt...Pt distance will form sterically distinct DNA adducts, resulting in different cytotoxic profiles. This paper describes synthesis and characterization of the azine-bridged dinuclear platinum complexes, their reaction mechanisms with guanosine5 -monophosphate (GMP), and the results of cytotoxicity tests.

\section{Results}

Synthesis and Characterization of the AzineBridged Complexes. Cisplatin was reacted with 1 equiv of $\mathrm{AgNO}_{3}$ to replace one chloride by a DMF molecule (Scheme 1). To the monoactivated species in DMF solution an azine was added and incubated at room temperature to form an azine-bridged complex. The solution was evaporated, and the resulting material was recrystallized from aqueous solution. The formation of $\mathbf{3}$ is significantly slower than that of the other complexes, and the synthesis of this compound appears to be accompanied by formation of [cis- $\mathrm{Pt}\left(\mathrm{NH}_{3}\right)_{2}(\mu-$ $\left.\mathrm{pdn})_{2}\right]^{4+}$, which was characterized by ${ }^{1} \mathrm{H}$ and ${ }^{195} \mathrm{Pt} \mathrm{NMR}$ and X-ray crystal analysis, as a side product.

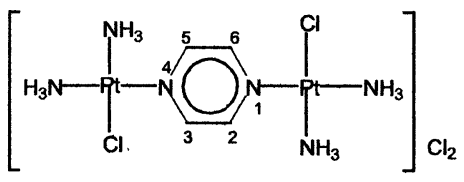

$\left[\left\{\text { cis-Pt }\left(\mathrm{NH}_{3}\right)_{2} \mathrm{Cl}\right\}_{2}(\mu-\mathrm{pzn})\right] \mathrm{Cl}_{2}(\mathbf{1 a})$

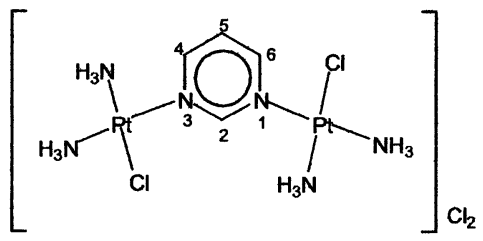

$\left[\left\{\right.\right.$ cis-Pt $\left.\left(\mathrm{NH}_{3}\right)_{2} \mathrm{Cl}_{2}(\mu-\mathrm{pmn})\right] \mathrm{Cl}_{2}(2)$
Table 1. ${ }^{1} \mathrm{H}$ and ${ }^{195} \mathrm{Pt}$ NMR Data for the Azine-Bridged Dinuclear Platinum(II) Complexes $\left(\mathrm{D}_{2} \mathrm{O}\right)$

\begin{tabular}{llr}
\hline compound & \multicolumn{1}{c}{ azine, $\delta\left({ }^{1} \mathrm{H}\right), \mathrm{ppm}$} & $\begin{array}{c}\left({ }^{195} \mathrm{Pt}\right) \text {, } \\
\mathrm{ppm}\end{array}$ \\
\hline $\mathbf{1 a}$ and $\mathbf{1 b}$ & $9.04(\mathrm{H} 2, \mathrm{H} 3, \mathrm{H} 5, \mathrm{H} 6(\mathrm{~s}))$ & -2302 \\
$\mathbf{2}$ & $10.03(\mathrm{H} 2(\mathrm{~s})), 9.28(\mathrm{H} 4, \mathrm{H} 6(\mathrm{~d})), 7.86(\mathrm{H} 5(\mathrm{t}))$ & -2323 \\
$\mathbf{3}$ & $9.62(\mathrm{H} 3, \mathrm{H} 6), 8.13(\mathrm{H} 4, \mathrm{H} 5)$ & -2251 \\
\hline
\end{tabular}

Table 2. Selected Bond Distances ( $\AA$ ) Angles (deg) in $\left[\left\{\text { cis-Pt }\left(\mathrm{NH}_{3}\right)_{2} \mathrm{Cl}\right\}_{2}(u-\mathrm{pzn})\right]\left(\mathrm{NO}_{3}\right)_{2}(\mathbf{l b})^{a}$

$\begin{array}{ll}\mathrm{Pt}(1)-\mathrm{Cl}(1) & 2.2953(13) \\ \mathrm{Pt}(1)-\mathrm{N}(1) & 2.007(4) \\ \mathrm{Pt}(1)-\mathrm{N}(4) & 2.032(5) \\ \mathrm{Pt}(1)-\mathrm{N}(5) & 2.034(4) \\ \mathrm{Pt}(1)-\mathrm{Pt}(1)^{\prime} & 6.7823(5) \\ \mathrm{Cl}(1)-\mathrm{Pt}(1)-\mathrm{N}(1) & 91.39(14) \\ \mathrm{Cl}(1)-\mathrm{Pt}(1)-\mathrm{N}(4) & 177.20(19) \\ \mathrm{Cl}(1)-\mathrm{Pt}(1)-\mathrm{N}(5) & 88.76(14) \\ \mathrm{N}(1)-\mathrm{Pt}(1)-\mathrm{N}(4) & 89.6(2) \\ \mathrm{N}(1)-\mathrm{Pt}(1)-\mathrm{N}(5) & 176.64(19) \\ \mathrm{N}(4)-\mathrm{Pt}(1)-\mathrm{N}(5) & 90.4(2)\end{array}$

a Symmetry operation: $=1-x, 1-y, 1-z$.

The azine-bridged complexes were characterized by ${ }^{1} \mathrm{H}$ and ${ }^{195} \mathrm{Pt}$ NMR spectroscopy (see Table 1 ). In the ${ }^{1} \mathrm{H}$ NMR spectra for all platinum complexes the signals of the aromatic protons of the bridging azines are shifted downfield, compared to each of their free ligands. The range of ${ }^{195} \mathrm{Pt}$ chemical shifts of $\mathbf{1 a}, \mathbf{1 b}, \mathbf{2}$, and $\mathbf{3}$ confirmed a $\left[\mathrm{N}_{3} \mathrm{Cl}\right]$ platinum coordination sphere, ${ }^{26}$ indicating the formation of the desired compounds.

Crystal Structure of [\{cis-Pt $\left.\left(\mathrm{NH}_{3}\right)_{2} \mathbf{C l}\right\}_{2}(\mu$-pzn $\left.)\right]-$ $\left(\mathbf{N O}_{3}\right)_{\mathbf{2}}$ (1b). $\mathbf{1 b}$ crystallizes in the centrosymmetric space group $\mathrm{P}_{1} / \mathrm{c}$ with $Z=2$. Details are given in Supporting I nformation. The cation $\left[\left\{\text { cis- } P t\left(\mathrm{NH}_{3}\right)_{2} \mathrm{Cl}\right\}_{2^{-}}\right.$ $(u$-pzn $)]^{2+}$ has inversion symmetry. A PLATON drawing of the molecular structure of the cation is depicted in Figure 2. Selected bond distances and angles are given in Table 2. Like in the crystal structure of the azolebridged complexes, ${ }^{22}$ the $\mathrm{Pt}-\mathrm{N}$ (pyrazine) bonds are found to be slightly shorter than the $\mathrm{Pt}-\mathrm{N}$ (ammine) bonds. The $\mathrm{Pt}-\mathrm{Cl}$ bond lengths are in the expected range; similar distances were found in the crystal structure of other platinum complexes with an $\left[\mathrm{N}_{3} \mathrm{Cl}\right]$ environment. ${ }^{26}$ The interplanar angle between the $\mathrm{Pt}$ coordination plane and the pyrazine ring plane amounts to $58.3(2)^{\circ}$. The Pt atoms are square-planar coordinated<smiles>NC(N)(Cl)n1cc[n+](C(N)(N)Cl)c1</smiles>

$\left[\left\{\text { cis-Pt }\left(\mathrm{NH}_{3}\right)_{2} \mathrm{Cl}\right\}_{2}(\mu-\mathrm{pzn})\right]\left(\mathrm{NO}_{3}\right)_{2}(\mathbf{1 b})$

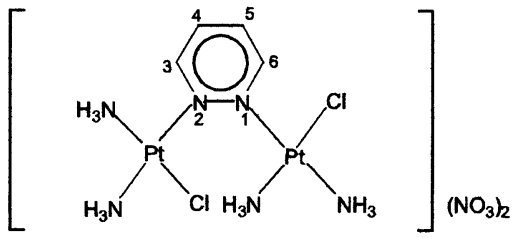

$\left[\left\{\text { cis-Pt }\left(\mathrm{NH}_{3}\right)_{2} \mathrm{Cl}\right\}_{2}(\mu\right.$-pdn $\left.)\right]\left(\mathrm{NO}_{3}\right)_{2}(3)$

Figure 1. Schematic representation of $\left[\left\{\mathrm{cis}-\mathrm{Pt}\left(\mathrm{NH}_{3}\right)_{2} \mathrm{Cl}\right\}_{2}(\mu-\mathrm{pzn})\right] \mathrm{Cl}{ }_{2}(\mathbf{l a})$, [\{cis-Pt $\left.\left.\left(\mathrm{NH}_{3}\right)_{2} \mathrm{Cl}\right\}_{2}(\mu-\mathrm{pzn})\right]\left(\mathrm{NO}_{3}\right)_{2}$ (1) $\mathrm{Cl}_{2}(\mu-\mathrm{pmn}) \mathrm{Cl}_{2}(\mathbf{2})$, and $\left[\left\{\mathrm{cis}-\mathrm{Pt}\left(\mathrm{NH}_{3}\right)_{2} \mathrm{Cl}\right\}_{2}(\mu-\mathrm{pdn})\right]\left(\mathrm{NO}_{3}\right)_{2}$ (3). 


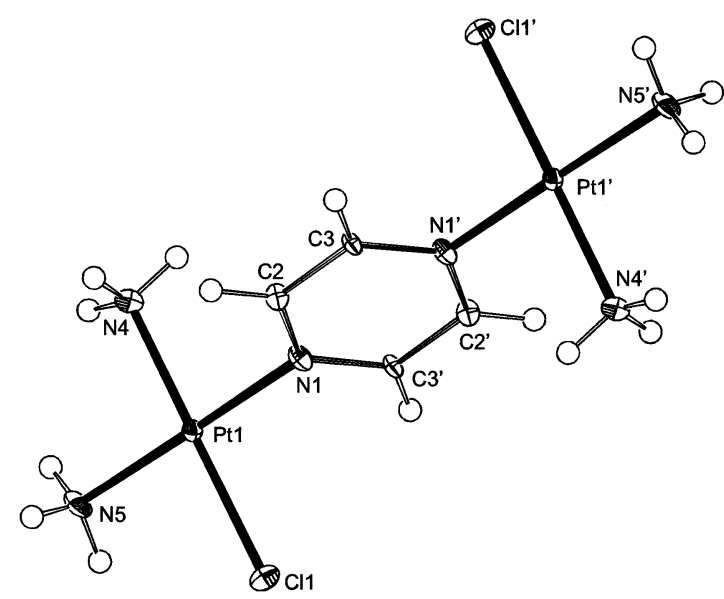

Figure 2. Displacement ellipsoid plot ( $50 \%$ probability) of the cation $\left[\left\{\text { cis-Pt }\left(\mathrm{NH}_{3}\right)_{2} \mathrm{Cl}\right\}_{2}(\mu \text {-pzn })\right]^{2+}$ in the crystal structure of 1b. The nitrate anions were omitted for clarity. $\mathrm{H}$ atoms were introduced at calculated positions, and the ammine hydrogens were refined with a rotating model.

(angle sum is $360.0^{\circ}$ ), and no significant deviation from the right angle is present within the $\left[\mathrm{PtN}_{3} \mathrm{Cl}\right]$ unit. As a result of the two para-arranged nitrogen donor atoms of pyrazine, the distance between intramolecular $\mathrm{Pt}$ atoms $(6.7823(5) \AA$ ) is almost twice as long as those found in [ $\left.\left\{\text { cis-Pt }\left(\mathrm{NH}_{3}\right)_{2}\right\}_{2}(u-\mathrm{OH})(u-1,2,3-\mathrm{ta}-\mathrm{N} 1, \mathrm{~N} 2)\right]\left(\mathrm{NO}_{3}\right)_{2}$, [ $\left\{\text { cis-Pt }\left(\mathrm{NH}_{3}\right)_{2}\right\}_{2}(\mu-\mathrm{OH})(\mu$-4-phe-1,2,3-ta-N 1,N 2)]$\left(\mathrm{NO}_{3}\right)_{2}$, and [ $\left\{\mathrm{Pt}(\text { trans-dach }\}_{2}(u-\mathrm{OH})(u-\mathrm{pz})\right]\left(\mathrm{NO}_{3}\right)_{2}(3.44-$ $3.49 \AA) .22,23$

In the crystal lattice the complex cations are arranged in layers, which are stacked on top of each other in the direction of the crystallographic b-axis. The cations within these layers are tilted with respect to the screw axis al ong $b$ (the plane of the pyrazine ring has an angle of $74.37(17)^{\circ}$ to the b-axis) forming a herringbone type of packing. These cationic layers are cemented by layers of nitrate anions. The ammine ligands are donors of hydrogen bonds toward the metal bound chlorine and the nitrate anions as acceptors.

Reaction of $1 \mathrm{a}, 2$, and 3 with GMP. 1a. The ${ }^{1} \mathrm{H}$ NMR spectra of the reaction of 1 with 2 equiv of GMP in $0.1 \mathrm{M} \mathrm{NaClO}_{4} / \mathrm{D}_{2} \mathrm{O}$ solution are shown in Figure $3 \mathrm{a}$. As the reaction proceeds, the $\mathrm{H} 8$ signal of free GMP at $8.18 \mathrm{ppm}$ decreases in intensity, while the intensity of the $\mathrm{H} 8$ signal $(8.91 \mathrm{ppm})$ corresponding to the $1: 2$ complex, [ $\left.\left\{\text { cis-Pt }\left(\mathrm{NH}_{3}\right)_{2}(\mathrm{GMP}-\mathrm{N} 7)\right\}_{2}(u-\mathrm{pzn})\right]\left(\mathbf{I}-(\mathrm{GMP})_{2}\right)$, increases. The supposed intermediate species could hardly be detected (see Scheme 2). For the assignment of $\mathbf{I}-(\mathrm{GMP})_{2}$, the ${ }^{1} \mathrm{H}$ and ${ }^{195} \mathrm{Pt}$ NMR spectra confirms the symmetry of the bridging pzn (single signal at 9.13 $\mathrm{ppm}$ ) and $\left[\mathrm{N}_{4}\right]$ platinum(II) coordination spheres $22,23,27$ (see Table 3).

2. The ${ }^{1} \mathrm{H}$ NMR spectra of the reaction of $\mathbf{2}$ with 2 equiv of GMP in $0.1 \mathrm{M} \mathrm{NaClO}_{4}$ solution and its supposed reaction scheme are shown in Figure $3 b$ and Scheme 2, respectively. The complex 2 provides the 1:2 complex, [ cis-Pt $\left.\left(\mathrm{NH}_{3}\right)_{2}(\mathrm{GMP}-\mathrm{N} 7)\right\}_{2}(u$-pmn $\left.)\right]\left(\mathrm{II}-(\mathrm{GMP})_{2}\right)$ with a certain amount of the intermediate species [\{cis-Pt$\left.\left(\mathrm{NH}_{3}\right)_{2}(\mathrm{GMP}-\mathrm{N} 7)\right\}(u$-pmn $\left.)\left\{\mathrm{cis}-\mathrm{Pt}\left(\mathrm{NH}_{3}\right)_{2}\left(\mathrm{H}_{2} \mathrm{O}\right)\right\}\right]^{2+}(\mathrm{II}-$ $\left.(\mathrm{GMP})\left(\mathrm{H}_{2} \mathrm{O}\right)\right)$ observed. The formation of diverse intermediate species including those similar to II-(GMP)$\left(\mathrm{H}_{2} \mathrm{O}\right)$, has been observed previously during the reaction of platinum(II) complexes with GMP. ${ }^{28-32}$ In the ${ }^{1} \mathrm{H}$ NMR spectrum of $\mathbf{I I}-(\mathrm{GMP})_{2}$, one signal assigned as the $\mathrm{H} 4$ and $\mathrm{H} 6$ of the pmn ring confirms the symmetry profile of the molecule about the bridging ligand. On the other hand, in the case of II-(GMP) $\left(\mathrm{H}_{2} \mathrm{O}\right)$, two different ${ }^{1} \mathrm{H}$ NMR signals for $\mathrm{H} 4$ and $\mathrm{H} 6$ and two ${ }^{195} \mathrm{Pt}$ signals at -1997 and $-2470 \mathrm{ppm}$ with the same intensity confirm the asymmetry of the molecule and the presence of $\left[\mathrm{N}_{3} \mathrm{O}_{1}\right]$ and $\left[\mathrm{N}_{4}\right]$ platinum(II) coordination spheres in the molecule. $22-24,27$ The presence of this intermediate species suggests that the second substitution by GMP proceeds at a slower rate compared to that of $\mathbf{1}$, probably due to the steric hindrance caused by closer proximity of the two platinum(II) coordination spheres. Accordingly, the bulky GMP ligand of II$(\mathrm{GMP})\left(\mathrm{H}_{2} \mathrm{O}\right)$ may prevent the second GMP from coordination to another platinum atom. The reactions with excess (4 equiv) of GMP yield the same products as those resulting from stoichiometric conditions, but the amount of II-(GMP) $\left(\mathrm{H}_{2} \mathrm{O}\right)$ formed under these conditions is much smaller. Surprisingly, during the same reaction in $0.1 \mathrm{M} \mathrm{NaCl} \mathrm{D}_{2} \mathrm{O}$ solution formation of II-(GMP)$\left(\mathrm{H}_{2} \mathrm{O}\right)$ is not suppressed in favor of the other probable intermediate species [ $\left\{\right.$ cis-Pt $\left.\left(\mathrm{NH}_{3}\right)_{2}(\mathrm{GMP}-\mathrm{N} 7)\right\}(u$-pmn)$\left\{\right.$ cis-Pt $\left.\left.\left.\left(\mathrm{NH}_{3}\right)_{2} \mathrm{Cl}\right)\right\}\right]^{2+}(\mathbf{I I}-(\mathrm{GMP}) \mathrm{Cl})$. Therefore, a hydrogen bond of the $\mathrm{H}_{2} \mathrm{O}$ ligand with phosphate, or with $\mathrm{O} 6$ of a GMP bound to another platinum atom, might be expected.

3. The ${ }^{1} \mathrm{H}$ NMR spectra of the reaction of $\mathbf{3}$ are shown in Figure 3c. The complex $\mathbf{3}$ was expected to react with 2 equiv of GMP, just as found for the other two azinebridged complexes. The reaction, however, appears to go parallel with the cleavage of one of the $\mathrm{Pt}-\mathrm{N}(\mathrm{pdn})$ bonds, resulting in reactions leading to three very interesting different final products, i.e., [cis-Pt $\left(\mathrm{NH}_{3}\right)_{2-}$ (pdn)(GMP-N 7)] ${ }^{2+}$ (III-a), [cis-Pt( $\left.\mathrm{NH}_{3}\right)_{2}(\mathrm{pdn})(\mathrm{GMP}-$ O6) $]^{2+}(\mathbf{I I I - b})$, and [\{cis-Pt $\left.\left(\mathrm{NH}_{3}\right)_{2}\right\}(\mu-\mathrm{GMP}-\mathrm{N} 7, \mathrm{O} 6)\{\mathrm{cis}-$ $\left.\left.\mathrm{Pt}\left(\mathrm{NH}_{3}\right)_{2}\right\}\right]_{\mathrm{n}}$ (IIII-c). A series of these reactions may look complicated, but could be explained as that $\mathbf{3}$ initially forms the 1:1 complex, [ [ cis-Pt $\left.\left(\mathrm{NH}_{3}\right)_{2}\right\}_{2}(\mu-\mathrm{GMP}-\mathrm{N} 7, \mathrm{O} 6)-$ $(\mu-p d n)]$, and the N7 of the second GMP replaces the N7 or $\mathrm{O} 6$ of the bridging GMP ligand, leading to the cl eavage of one of the $\mathrm{Pt}-\mathrm{N}(\mathrm{pdn})$ bonds due to the close proximity of the two intramolecular platinum atoms. As a result, the species, $\mathbf{I I I - a}, \mathbf{I I I - b}$, and [cis-Pt $\left(\mathrm{NH}_{3}\right)_{2^{-}}$ $\left.(\mathrm{GMP})\left(\mathrm{H}_{2} \mathrm{O}\right)\right]^{2+}$ are generated, and the latter species polymerizes to form III-c (see Scheme 3).

These three products were separated by gel filtration. The ${ }^{195} \mathrm{Pt}$ NMR spectra of III-a and III-b confirm the platinum coordination spheres to be $\left[\mathrm{N}_{4}\right]$ and $\left[\mathrm{N}_{3} \mathrm{O}_{1}\right]$, respectively. ${ }^{22,23,27}$ All the ${ }^{1} \mathrm{H}$ NMR chemical shifts corresponding to pdn protons are observed as independent signals, showing asymmetric profiles of the pdn. These observations obviously supports the cleavage of one of the two Pt-N (pdn) bonds. For species III-c, which elutes out of the column in the first fraction, no ${ }^{1} \mathrm{H}$ NMR signals corresponding to the pdn ring, but only those originating from GMP are observed. The $\mathrm{H} 8$ signal shifted $0.51 \mathrm{ppm}$ downfield compared to a free GMP, indicating an inductive effect by the platinum coordination on the guanine base. Therefore, at this juncture, it is clear that species III-c is a Pt-GMP complex with absence of a pdn moiety. No ${ }^{195} \mathrm{Pt}$ NMR signal for this compound was observed. Such phenomenon is often observed in case of the polymerized compounds. ${ }^{33}$ The mass spectrum of this complex gives a signal corre- 


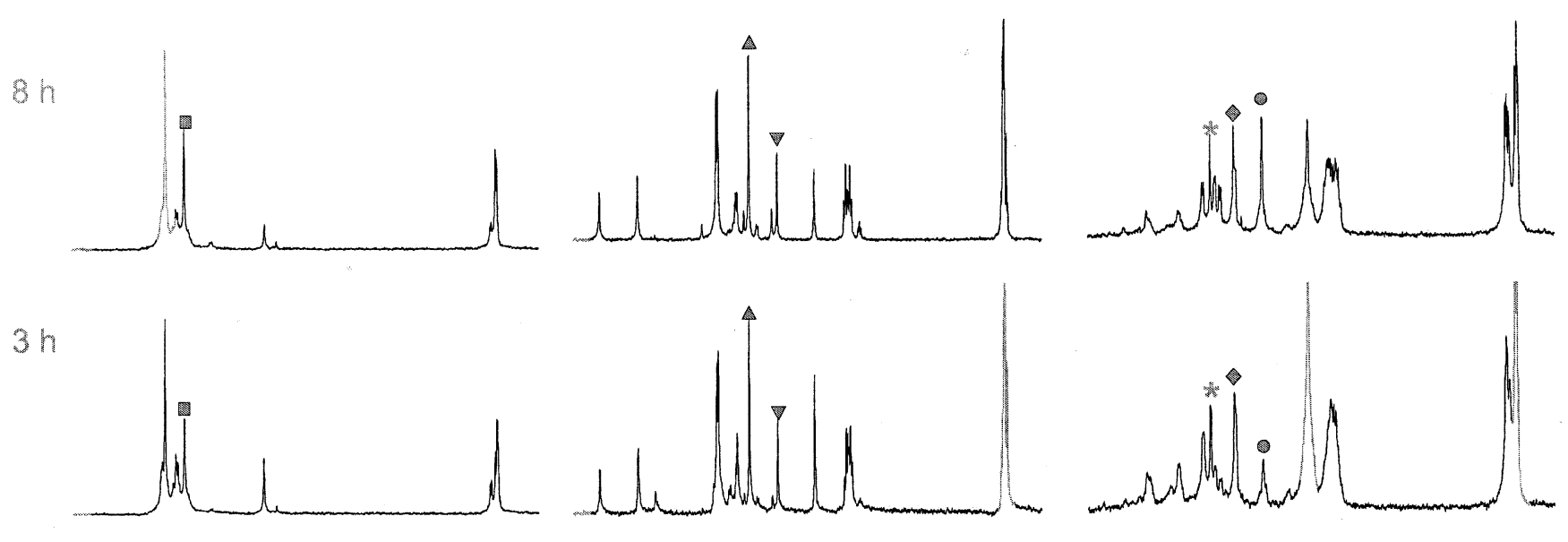

$2 h$
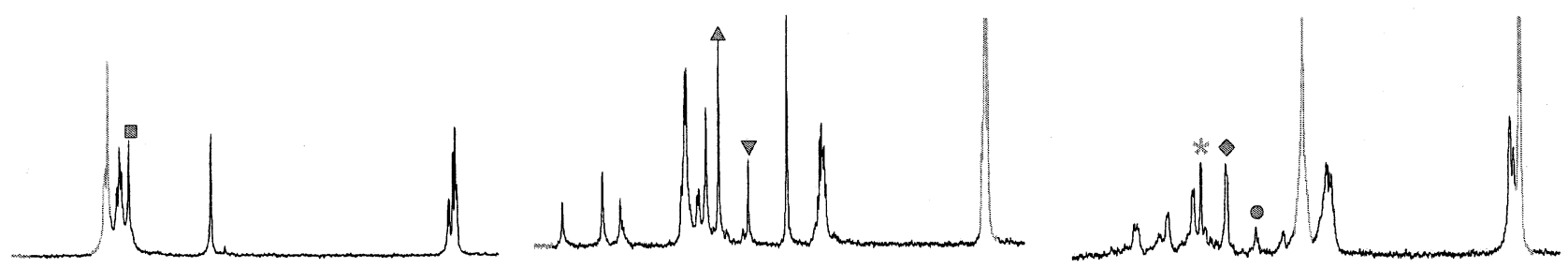

$1 \mathrm{~h}$
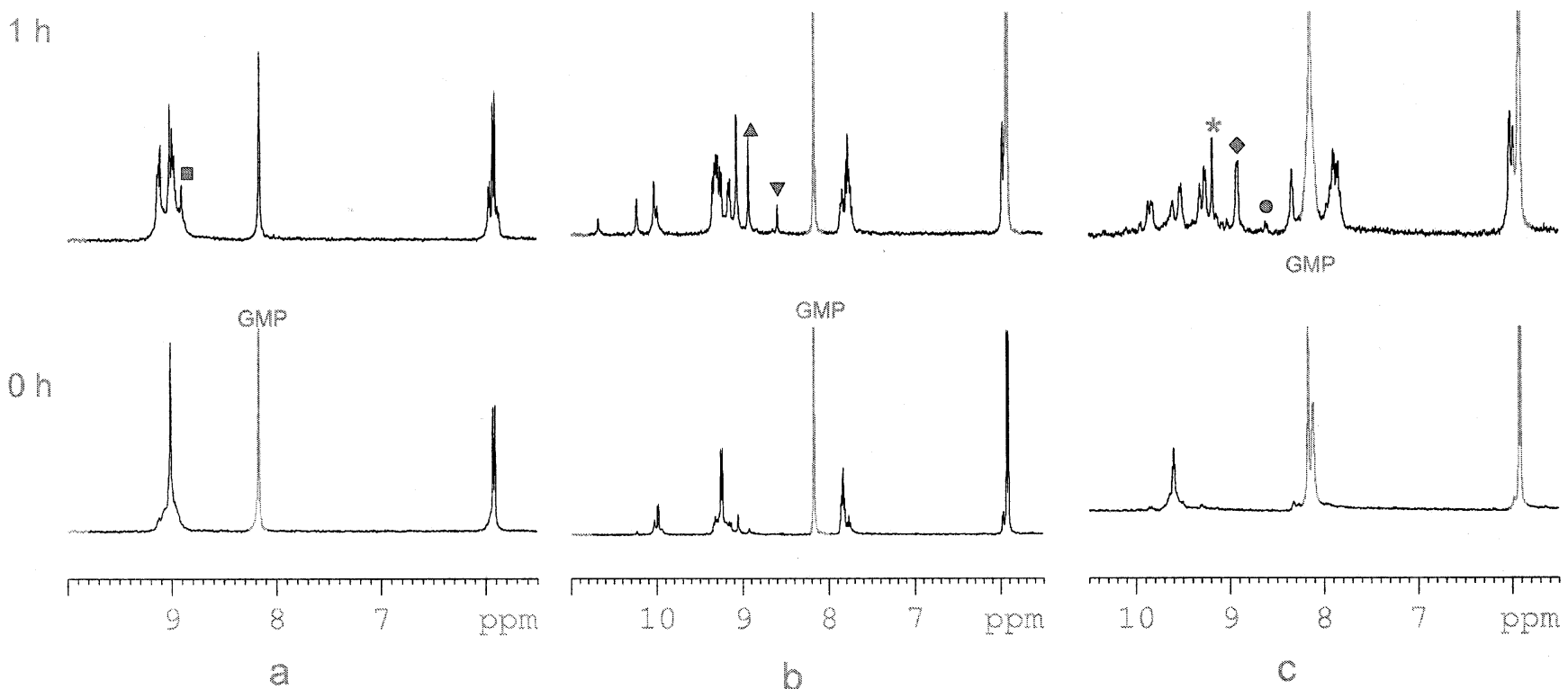

Figure 3. ${ }^{1} \mathrm{H} N M R$ spectra upon the reactions of $\mathbf{1}(\mathbf{a})$, $\mathbf{2}(\mathbf{b})$, and $\mathbf{3}(\mathbf{c})$ with 2 equiv of GMP in $0.1 \mathrm{M} \mathrm{NaClO}_{4} / \mathrm{D}_{2} \mathrm{O}$ solution (pD 7.5) measured at $310 \mathrm{~K}$. The symbols show the $\mathrm{H} 8$ signals of GMP ligands in the products, I- $-(\mathrm{GMP})_{2}(\mathbf{\square}), \mathbf{I I}-(\mathrm{GMP})\left(\mathrm{H}_{2} \mathrm{O}\right)(\mathbf{\nabla}), \mathbf{I I}-$

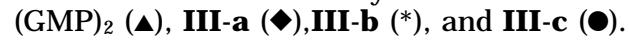

sponding to $\left[\left\{\mathrm{Pt}\left(\mathrm{NH}_{3}\right)_{2}(\mathrm{GMP})\right\}_{2} \mathrm{Pt}+2 \mathrm{H}\right]^{+}$. These observations lead to the conclusion that III-c is a polymerized species of the formula [ $\left\{\right.$ ais-Pt $\left.\left(\mathrm{NH}_{3}\right)_{2}\right\}(\mu$-GMP-N 7,O6) \{cis$\left.\left.\mathrm{Pt}\left(\mathrm{NH}_{3}\right)_{2}\right\}\right]_{n}$ (see Scheme 3), as suggested above. The formation of different, presumably dimeric and polymeric, species during the reaction of platinum complexes with GMP have been observed previously. 30,32,34,35 Different structures, such as a N 7-06 chelate, ${ }^{32}$ a platinum dimer with one $\mathrm{Pt}$ atom bound to $\mathrm{N} \mathrm{I}$ and another one bound to $\mathrm{N} 7,{ }^{34}$ and a polymer ${ }^{35}$ have been suggested. ${ }^{1} \mathrm{H}$ NMR data for III-c and the related species previously reported are summarized in Table 4.

Thus, III-c is likely to be the product previously observed by Chu et al. ${ }^{35}$ during the reaction of cis-
$\left[\left(\mathrm{NH}_{3}\right)_{2} \mathrm{Pt}\left(\mathrm{H}_{2} \mathrm{O}\right)_{2}\right]^{2+}$ with GMP $(1: 1)$ in $\mathrm{D}_{2} \mathrm{O}$ at $\mathrm{pD} 8.8$ and higher. It should be noted that in our study the formation of III-c was observed at neutral $\mathrm{pH}$ and with the commonly used ratio of the reactants (1:2 and 1:4). This is the first example of polymerization that proceeds under such conditions. Another remarkable feature is that 3 does not survive the GMP attack, even though there is spectroscopic evidence for stepwise hydrolysis of this complex, in which the Pt-( $\mu$-pdn)-Pt moiety remains intact (data not shown). Such an outcome most likely is caused by the close proximity of two intramolecular platinum atoms in 3 . Even in the crystal structure of $\left[\left\{\mathrm{cis}-\mathrm{Pt}\left(\mathrm{NH}_{3}\right)_{2}(9 \mathrm{EtG})\right\}_{2}(\mu-\mathrm{pz})\right]^{3+}$, the intramolecular Pt...Pt distance is slightly enlarged com- 
Scheme 2. Proposed Reaction Scheme for the Interaction of $\mathbf{1}$ and $\mathbf{2}$ with 2 equiv of GMP in Aqueous Solution
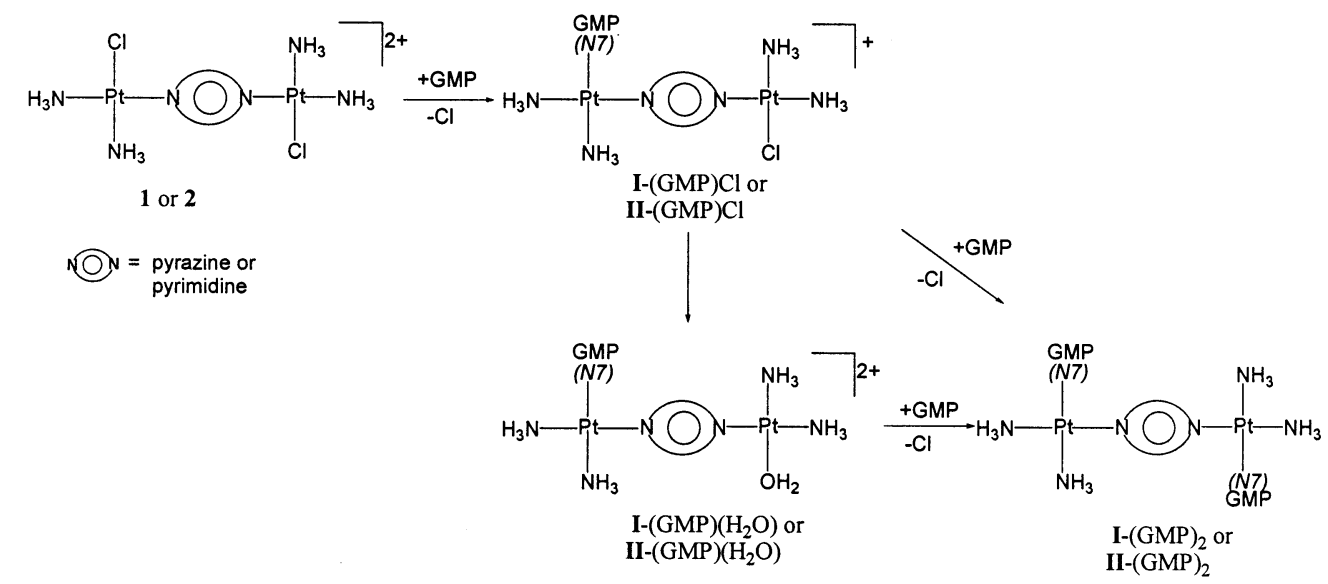

Table 3. ${ }^{1} \mathrm{H}$ and ${ }^{195} \mathrm{Pt}$ NMR Data of the Reaction Products, I- $(\mathrm{GMP})_{2}, \mathbf{I I}-(\mathrm{GMP})\left(\mathrm{H}_{2} \mathrm{O}\right)$, II $-(\mathrm{GMP})_{2}$, III -a and III -b, and III-c in $\mathrm{D}_{2} \mathrm{O}$ Solution (pD 7) at $298 \mathrm{~K}$

\begin{tabular}{|c|c|c|c|c|}
\hline \multirow[b]{2}{*}{ compound } & \multicolumn{3}{|c|}{$\delta\left({ }^{1} \mathrm{H}\right), \mathrm{ppm}$} & \multirow[b]{2}{*}{$\delta\left({ }^{195} \mathrm{Pt}\right), \mathrm{ppm}$} \\
\hline & $\mathrm{H} 8$ & $H 1^{\prime}\left(I_{1^{\prime}-2^{\prime}}, \mathrm{Hz}\right)$ & azines & \\
\hline GMP & 8.18 & $5.91(5.7)$ & - & - \\
\hline $\mathbf{I}-(\mathrm{GMP})_{2}$ & 8.91 & $5.86(3.7)$ & $9.13(\mathrm{H} 2, \mathrm{H} 3, \mathrm{H} 5, \mathrm{H} 6)$ & -2454 \\
\hline $\mathrm{II}-(\mathrm{GMP})\left(\mathrm{H}_{2} \mathrm{O}\right)$ & 8.60 & $5.96(4.1)$ & $\begin{array}{l}10.64(\mathrm{H} 2), 9.28(\mathrm{H} 4 \text { or } \mathrm{H} 6) \\
9.08(\mathrm{H} 4 \text { or } \mathrm{H} 6), 7.82(\mathrm{H} 5)\end{array}$ & $\begin{array}{l}-1997 \\
-2470\end{array}$ \\
\hline $\mathbf{I I}-(\mathrm{GMP})_{2}$ & 8.97 & $5.95(4.1)$ & $\begin{array}{l}10.29(\mathrm{H} 2), 9.34(\mathrm{H} 4, \mathrm{H} 6) \\
7.77(\mathrm{H} 5)\end{array}$ & -2468 \\
\hline$I I I-a^{a}$ & 9.02 & $6.01(4.8)$ & $\begin{array}{l}9.14(\mathrm{H} 6), 9.07(\mathrm{H} 3) \\
7.94(\mathrm{H} 5), 7.80(\mathrm{H} 4)\end{array}$ & -2430 \\
\hline $\mathbf{I I I - b ^ { a }}$ & 9.16 & $6.05(3.4)$ & $\begin{array}{l}9.30(\mathrm{H} 6), 8.95(\mathrm{H} 3) \\
8.13(\mathrm{H} 5), 7.90(\mathrm{H} 4)\end{array}$ & -1999 \\
\hline III-C & 8.69 & $5.92(4.7)$ & - & n.o. ${ }^{b}$ \\
\hline
\end{tabular}

a $\mathrm{F}$ or the characterization of the pyridazine protons, refer to the numbering in Scheme 3. ${ }^{\mathrm{b}} \mathrm{N}$ ot observed. ${ }^{33}$

Scheme 3. Supposed Reaction Scheme for the Interaction of $\mathbf{3}$ with 2 equiv of GMP in Aqueous Solution

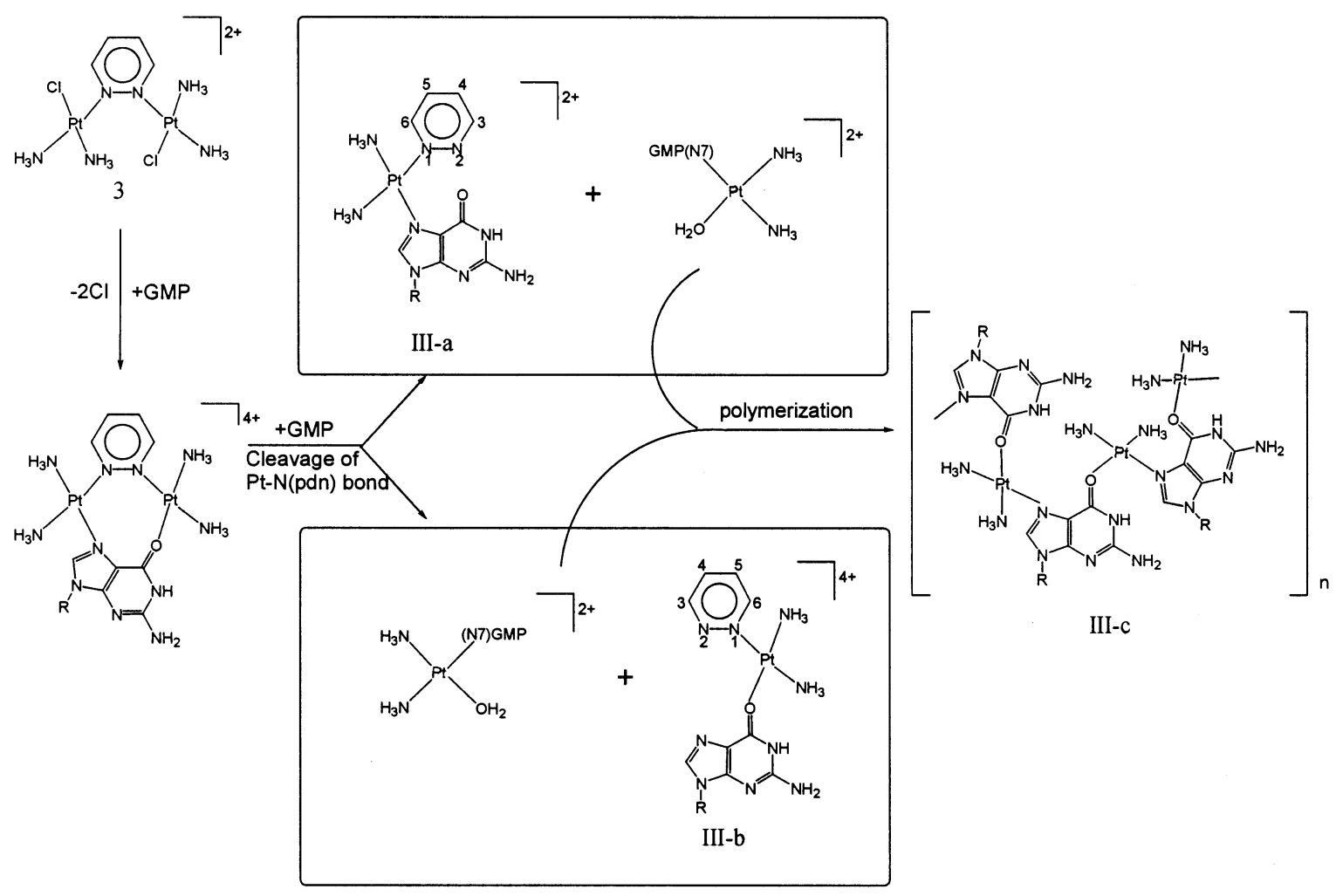

pared with $\left.\left[\text { cis- } \mathrm{Pt}\left(\mathrm{NH}_{3}\right)_{2}\right\}_{2}(\mu-\mathrm{OH})(\mu-\mathrm{pz})\right]^{2+}, 24$ showing its sterically constrained geometry. The Pt...Pt distance of $\mathbf{3}$ should be significantly smaller than that of [\{cis-Pt-
$\left.\left.\left(\mathrm{NH}_{3}\right)_{2}\right\}_{2}(\mu-\mathrm{OH})(\mu-\mathrm{pz})\right]^{2+}$, due to the different $\mathrm{sp}^{2}$ coordination between five- and six-membered aromatic rings. 
Table 4. ${ }^{1} \mathrm{H}$ NMR Data ( $\mathrm{H} 8$ and $\mathrm{HI}^{\prime}$ ) for the GMP Ligands in III-c and Similar Species Known from the Literature (the shifts are given in reference to TSP)

\begin{tabular}{lcc}
\hline \multicolumn{1}{c}{ compound } & $\delta(\mathrm{H} 8), \mathrm{ppm}$ & $\delta\left(\mathrm{H}^{\prime}\right.$ ), $\mathrm{ppm}$ \\
\hline N1,N7-platinated dimer [34] & 8.45 & n.a. \\
N7,O6-platinated dimer [30] & 8.56 & 5.21 \\
N7-O6-chelate [32] & 8.41 & n.a. \\
N7,O6-platinated polymer [35] & 8.67 & 5.87 \\
III-c & 8.69 & 5.92 \\
\hline
\end{tabular}

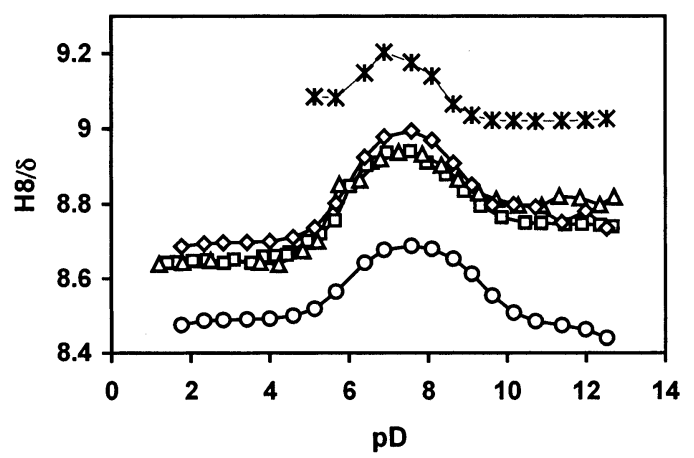

Figure 4. Plots of the chemical shift $(\delta)$ of the $\mathrm{H} 8$ resonance vs $\mathrm{pD}$ for I-(GMP) $)_{2}(\square), \mathbf{I I}-(\mathrm{GMP})_{2}(\triangle)$, III-a $(\diamond), \mathbf{I I I - b}(*)$, and III-c $(O)$. pH titrations were performed in nonbuffer $\mathrm{D}_{2} \mathrm{O}$ solutions at $298 \mathrm{~K}$. pD was adjusted with $0.1 \mathrm{M} \mathrm{DCl}$ and 0.1 $\mathrm{M} \mathrm{NaOD}$.

pH Dependence of H8 Chemical Shift of the Final Products. A pH titration is a very useful method ${ }^{7,8}$ to confirm the structure of the adducts of platinum complexes with GMP, since the protonation of heterocyclic nitrogen atoms and phosphate group of GMP has a strong influence on the chemical shift of the $\mathrm{H} 8$ proton. So, the $\mathrm{pH}$ titration of the products (I$(\mathrm{GMP})_{2}, \mathbf{I I}-(\mathrm{GMP})_{2}, \mathbf{I} \mathbf{I} \mathbf{- a}, \mathbf{I} \mathbf{I}-\mathbf{b}$, and $\left.\mathbf{I I} \mathbf{I}-\mathbf{c}\right)$ was performed. The plots of the chemical shifts of $\mathrm{H} 8$ proton as a function of $\mathrm{pD}$ are shown in Figure 4 . For the species I-(GMP) $)_{2}, \mathbf{I I}-(\mathrm{GMP})_{2}, \mathbf{I I} \mathbf{I}-\mathbf{a}$, and III-c the N7(de)protonation in the acidic area, as it is known for free GMP, is absent. Thus, all of them contain a Pt atom coordinated at a N7 position. For all the species (de)protonation at $\mathrm{N} 1$ was observed and appeared to be a confirmation of the proposed structures, platinum coordinations at $\mathrm{N} 7$ and $\mathrm{O} 6$ on a guanine base. Unfortunately, III-b was found to be not stable at $\mathrm{pD}<4.4$, making it difficult to confirm the absence of platinum at $\mathrm{N} 7$ in this case.

Kinetic Aspects. The reactions of the complexes $\mathbf{1 a}$, 2, and 3 with GMP (1:2 and 1:4) in both $0.1 \mathrm{M} \mathrm{NaCl}$ and $0.1 \mathrm{M} \mathrm{NaClO}_{4} \mathrm{D}_{2} \mathrm{O}$ solutions were followed by ${ }^{1} \mathrm{H}$ NMR spectroscopy. The reaction of $\mathbf{3}$ with GMP was not kinetically quantified, due to an overlap between the H8 signal of free GMP and the signals of aromatic protons of the pyridazine ligand. The half-lives $\left(t_{1 / 2}\right)$ of GMP (for the 1:2 reactions) and times of disappearance of $25 \%\left(t_{1 / 4}\right)$ of GMP (for the $1: 4$ reactions) were determined graphically based on relative integration values of $\mathrm{H} 8$ proton. The respective $t_{1 / 2}(G M P)$ and $\mathrm{t}_{1 / 4}(\mathrm{GMP})$ values for the complexes $\mathbf{1 a}$ and $\mathbf{2}$ are given in Table 5. The half-times of formation of the major products are shown in Table 6.

It is clear from Table $\mathbf{6}$ that in the case of $\mathbf{1 a}$ and $\mathbf{2}$ the reaction rate is proportional to the starting concentration of GMP, as expected for second-order reactions. The reaction rate, either with an excess of $\mathrm{Cl}^{-}$or in the
Table 5. The Times of Disappearance of $50 \%\left(t_{1 / 2}\right.$ for $1: 2$ Reaction) and $25 \%$ ( $\mathrm{t}_{1 / 4}$ for 1:4 Reaction) GMP during the Reactions with $\mathbf{l a}$ and $\mathbf{2}$ under Various Conditions

\begin{tabular}{lcc}
\hline & $\mathrm{t}_{1 / 2}$ and $\mathrm{t}_{1 / 4}(\mathrm{~min})$ of $\mathrm{GMP}$ \\
\cline { 2 - 3 } conditions & 1a & $\mathbf{2}$ \\
\hline $0.1 \mathrm{M} \mathrm{NaClO}_{4}$ (4 equiv of GMP) & n.a. $^{\text {a }}$ & 60 \\
$0.1 \mathrm{M} \mathrm{NaCl}^{(4 \text { equiv of GMP) }}$ & 60 & 50 \\
$0.1 \mathrm{M} \mathrm{NaClO}_{4}$ (2 equiv of GMP) & 100 & 100 \\
$0.1 \mathrm{M} \mathrm{NaCl}$ (2 equiv of GMP) & 110 & 100 \\
\hline
\end{tabular}

a The starting complex precipitated in such a saturated solution.

Table 6. The Times of Formation of $50 \%\left(t_{1 / 2}\right.$ for $1: 2$ Reaction) and $25 \%$ ( $\mathrm{t}_{1 / 4}$ for $1: 4$ Reaction) of the 1:2 Complexes upon the Reactions of $\mathbf{1 a}$ and $\mathbf{2}$ with GMP under Various Conditions

\begin{tabular}{lcc}
\hline & \multicolumn{2}{c}{$\mathrm{t}_{1 / 2}$ and $\mathrm{t}_{1 / 4}$ (min) } \\
& for the formation of a final product \\
\cline { 2 - 3 } conditions & n.a. & $\mathbf{2}$ \\
\hline $0.1 \mathrm{M} \mathrm{NaClO}_{4}$ (4 equiv GMP) & 70 & 65 \\
$0.1 \mathrm{M} \mathrm{NaCl}^{\text {(4 equiv GMP) }}$ & 65 \\
$0.1 \mathrm{M} \mathrm{NaClO}_{4}$ (2 equiv GMP) & 100 & 200 \\
$0.1 \mathrm{M} \mathrm{NaCl}^{(2}$ equiv GMP) & 110 & 150 \\
\hline
\end{tabular}

a The starting complex precipitated in such a saturated solution.

absence of additional $\mathrm{Cl}^{-}$, is approximately the same. This indicates that the reactions of these complexes with GMP mainly proceed via direct substitution of a $\mathrm{Cl}^{-}$ ligand by N 7 of GMP. F or cisplatin, the rate-determing step for binding to a nucleic acid is known to be hydrolysis of a $\mathrm{Pt}-\mathrm{Cl}$ bond. ${ }^{27}$ Apparently, for these azine-bridged complexes $\mathbf{1}$ and $\mathbf{2}$, hydrolysis does not play an important role in the reaction with GMP. In fact, hydrolysis does occur in aqueous solution (without GMP), but with a significantly smaller rate (data are not shown here). Such a mode of interaction between platinum complexes and guanine model bases was al so suggested for dinuclear platinum complexes containing aliphatic diamines as bridging linkers. ${ }^{31}$ Therefore, steric factors appear to determine the reaction rate. The steric hindrance of $\mathbf{1}$ and $\mathbf{2}$ may not significantly differ for the first substitution reaction: as free rotation around $\mathrm{Pt}-\mathrm{N}$ (azine) bonds is present within both of them.

However, for the second substitution reaction, some effects of steric hindrance should be considered, because the $t_{1 / 2}$ value for the formation of the final product is found significantly lower for $\mathbf{2}$ than for $\mathbf{1}$ on the reaction with 2 equiv of GMP (see Table 6). As mentioned above, a certain amount of intermediate species II-(GMP)$\left(\mathrm{H}_{2} \mathrm{O}\right)$ is relieved during the reaction of 2 with 2 equiv of GMP, both in $\mathrm{NaClO}_{4}$ and in $\mathrm{NaCl} \mathrm{D}_{2} \mathrm{O}$ solution. No significant difference between $\mathbf{1}$ and $\mathbf{2}$ in the reaction with 4 equiv of GMP is observed, since the excess of GMP might simply suppress the formation of II-(GMP)$\left(\mathrm{H}_{2} \mathrm{O}\right)$ in this case.

Cytotoxicity. In Vitro Cytotoxicity Assay in Human Tumor Cell Lines. The cytotoxicity of $\mathbf{l a}, \mathbf{1 b}$, $\mathbf{2}$, and $\mathbf{3}$, and cisplatin as a reference, in several human tumor cell lines, MCF 7 and EVSA-T (breast cancer), WIDR (colon cancer), IGROV (ovarian cancer), M 19 (melanoma), A498 (renal cancer), and H226 (nonsmall cell lung cancer), is summarized in Table 7. All the azine-bridged complexes appear to be in the active range for all of the cell lines, except for H226. In five of these cell lines, the complexes are not as active as cisplatin. These complexes, however, do exhibit cytotoxicity higher 
Table 7. In Vitro Cytotoxicity Assay of the Azine-Bridged Dinuclear Platinum(II) Complexes and Cisplatin on Human Tumor Cell Linesa

\begin{tabular}{lrrrrrrrr}
\hline & \multicolumn{7}{c}{$\mathrm{IC}_{50}(\mu \mathrm{M})$} \\
\cline { 2 - 8 } test compd & MCF7 & EVSA-T & WIDR & IGROV & M19 & A498 & H226 \\
\hline la & 15.5 & 42.5 & 2.0 & 0.8 & 21.4 & 54.1 & $>91.9$ \\
$\mathbf{1 b}$ & 17.0 & 47.0 & 2.4 & 1.0 & 20.9 & 63.5 & $>85.2$ \\
$\mathbf{2}$ & 26.2 & 40.3 & 6.6 & 0.1 & 17.6 & 54.6 & $>91.9$ \\
$\mathbf{3}$ & 23.0 & $>85.2$ & 13.3 & 0.2 & 7.2 & 53.0 & $>85.2$ \\
cisplatin & 2.3 & 1.4 & 3.2 & 0.6 & 1.9 & 7.5 & 10.9
\end{tabular}

a MCF 7: breast cancer, EVSA-T: breast cancer, WIDR: colon cancer, IGROV: ovarian cancer, M 19: melanoma A498: renal cancer, H226: nonsmall cell lung cancer.

Table 8. In Vitro Cytotoxicity Assay of the Azine-bridged Dinuclear Platinum(II) Complexes and Cisplatin on L1210 Murine Leukemia Cell Lines Sensitive (L1210(0)) and Resistant (L 1210(cisPt)) to Cisplatin

\begin{tabular}{lccc}
\hline & \multicolumn{3}{c}{$\mathrm{IC}_{50}(\mu \mathrm{M})$} \\
\cline { 2 - 4 } test compd & $\mathrm{L} 1210(0)$ & $\mathrm{L} 1210($ cisPt $)$ & aRF \\
\hline $\mathbf{1 a}$ & $1.2 \pm 0.6$ & $2.5 \pm 0.5$ & 2.1 \\
$\mathbf{1 b}$ & $1.0 \pm 0.1$ & $3.5 \pm 0.1$ & 3.5 \\
$\mathbf{2}$ & $5.2 \pm 0.2$ & $18.4 \pm 1.0$ & 3.5 \\
$\mathbf{3}$ & $5.7 \pm 0.6$ & $21.3 \pm 3.0$ & 3.7 \\
cisplatin & $2.2 \pm 0.1$ & $14.6 \pm 3.5$ & 6.6
\end{tabular}

${ }^{a} \mathrm{RF}=$ the relative ratio of $\mathrm{IC}_{50}$ values in both cell lines (L 1210(cisPt)/L 1210(0)).

or comparable to cisplatin in both WIDR and IGROV. Especially, $\mathbf{2}$ appears to be 16 times more active than cisplatin. No significant difference seems to be present between $\mathbf{l a}$ and $\mathbf{1 b}$, implying at least a marginal influence of the different counterions (nitrate or chloride) on the cytotoxicity in this case.

The azine-bridged complexes show a remarkable cytotoxic profile with a high specificity for the IGROV cell line, and to a lesser extend the WIDR cell line, that is not observed for cisplatin.

In Vitro Cytotoxicity Assay on L 1210 Cell Lines Sensitive and Resistant to Cisplatin. The cytotoxicity results of the azine-bridged complexes and cisplatin for L 1210 leukemia cell lines sensitive and resistant to cisplatin are summarized in Table 8. In the parental cell line, $\mathbf{1 a}$ and $\mathbf{1 b}$ display cytotoxicity comparable to cisplatin, and there seems to be no significant difference between chl oride and nitrate salts. The complexes $\mathbf{2}$ and 3 are found to be approximately 2.5 times less cytotoxic than cisplatin, but are still in the active range. For cisplatin the cytotoxicity is dramatically lower in the resistant cell line as expected, and the so-called resistance factor (RF) is found to be as high as 6.6. Meanwhile, the RF values for all the azine-bridged complexes are smaller than for cisplatin. Especially, $\mathbf{1 a}$ and $\mathbf{1 b}$ exhi bit remarkable cytotoxicity in the resistant cell line.

\section{Discussion}

The isomeric azine-bridged complexes possess various Pt...Pt distances, which would bring sterically and sequentially distinct DNA adducts from each other and cisplatin. A significant difference in cytotoxicity is observed between complexes with the para-arranged linkers (pzn) and the sets of ortho- and meta-arrangements ( $p d n$ and pmn). J udging from the intramolecular Pt...Pt distance of $\mathbf{1}$, the 1,2-intrastrand cross-links are not likely to be produced on DNA, whereas 1,3- and 1,4intrastrand cross-links, and interstrand cross-links seem more probable. For $\mathbf{2}$, the rotations about Pt$\mathrm{N}(\mathrm{pmn})$ axes may allow the formation of similar intrastrand cross-links. The decomposition of $\mathbf{3}$ upon interaction with GMP appears to be rather reasonable, because of the close proximity of intramolecular $\mathrm{Pt}$ atoms. Unlike the case of the reaction with GMP, it is hard to accept that $\mathbf{3}$ would coordinate to the N7 and O6 of one guanine base on double-stranded DNA, since the $\mathrm{O} 6$ is a hydrogen bond acceptor on Watson-Crick base paring. Assuming that a nucleophilic base, such as guanine, is still present next to the base monoplatinated by 3 , one of the $\mathrm{Pt}-\mathrm{N}(\mathrm{pdn})$ bonds will be cleaved by its nucleophilic attack. As a result two platinated moi eties, i.e., [cis-Pt $\left(\mathrm{NH}_{3}\right)_{2}$ (pdn)(GMP-N 7)] and [cis-Pt$\left.\left(\mathrm{NH}_{3}\right)_{2}(\mathrm{GMP}-\mathrm{N} 7)\left(\mathrm{H}_{2} \mathrm{O}\right)\right]$, may be formed. The former will stay as a monofunctional adduct, and in case of the latter a further coordination to a nucleobase can be expected, just like in the case of cisplatin.

Both cisplatin and the novel azine-bridged dinuclear platinum(II) complexes possess two $\mathrm{Cl}$ ligands as leaving groups, and $\mathbf{1}$ and $\mathbf{2}$ indeed react with 2 equiv of GMP with rates comparable to cisplatin. These reactions, however, appear to proceed primarily with an associative mechanism, such as a direct substitution of the N7 of GMP for the Cl ligand, whereas the ratedeterming step for cisplatin is known to be hydrolysis. ${ }^{8}$ This difference might be explained by a positive charge of the azine-bridged complexes in contrast to neutral cisplatin. The results described above have shown that all azine-bridged complexes tested exhibited similar cytotoxic profiles in human tumor cell lines, and largely or partly circumvent cisplatin cross-resistance. In this juncture, it might be reasonable to state that all these complexes overcome the cross-resistance, owing to the DNA binding mode different from cisplatin.

Compared to the related promising azole-bridged dinuclear platinum(II) complexes, ${ }^{22}$ the azine-bridged complexes are less cytotoxic. A common structural feature of these two classes of dinuclear platinum(II) complexes is that both possess rigid aromatic rings (azole or azine) as bridging ligands, and a striking contrast between them is the dispositions of the leaving groups (hydroxo or chloride) in the molecules. The azolebridged complexes show much slower kinetics upon binding to nucleic acids. ${ }^{23}$ Ther efore, their slow reactivity could be attributed to high cytotoxicity, al though the steric difference of the DNA adducts should not be neglected.

\section{Concluding Remarks}

In this paper, we have reported the synthetic methods, reaction with GMP, and cytotoxicity of the isomeric azine-bridged complexes. The remarkable cytotoxicity in some cell lines and partially circumvented crossresistance to cisplatin confirm that the strategy to synthesize platinum(II) complexes, which provide apparently different DNA adducts, is a proper way to circumvent the cross-resistance. In fact, the synthetic methods for this kind of dinuclear platinum(II) compl exes are straightforward. Therefore, further preparation of new derivatives with a variety of azines will be of great interest and is a promising direction to be followed. 


\section{Experimental Section}

Materials. $\mathrm{K}_{2} \mathrm{PtCl}_{4}$ was used as obtained from J ohnson $\&$ Matthey (Reading, UK). Silver nitrate, pyrimidine, and pyridazine were purchased from ACROS. Pyrazine was purchased from J anssen Chimica. cis- $\mathrm{Pt}\left(\mathrm{NH}_{3}\right)_{2} \mathrm{Cl}_{2}$ (cisplatin) was synthesized as described previously. ${ }^{36}$ Guanosine-5'-monophosphate (GMP) was purchased from Sigma as the disodium salt.

Preparations of [cis-Pt( $\left.\left.\mathbf{N H}_{3}\right)_{2} \mathbf{C l}(\mathbf{d m f})\right]\left(\mathrm{NO}_{3}\right)$. A solution of $0.4 \mathrm{~g}$ of $\mathrm{AgNO}_{3}(2.35 \mathrm{mmol})$ in $10 \mathrm{~mL}$ of dimethylformamide (DMF) was added dropwise during $3 \mathrm{~h}$ to a stirred solution of $0.75 \mathrm{~g}$ of cis-Pt $\left(\mathrm{NH}_{3}\right)_{2} \mathrm{Cl}_{2}(2.5 \mathrm{mmol})$ in $40 \mathrm{~mL}$ of DMF at room temperature (RT) in the dark. The mixture was stirred overnight in the dark, and the $\mathrm{AgCl}$ precipitate was then filtered off. The resulting pale yellow DMF solution of [cis-Pt$\left.\left(\mathrm{NH}_{3}\right)_{2} \mathrm{Cl}(\mathrm{dmf})\right]\left(\mathrm{NO}_{3}\right)$ was used as the starting material for each preparation of the azine-bridged dinuclear platinum(II) complexes described below.

Preparations of $\left[\left\{\mathrm{cis}-\mathrm{Pt}\left(\mathrm{NH}_{3}\right)_{2} \mathrm{Cl}\right\}_{2}(\mu-\mathrm{pzn})\right] \mathrm{Cl}_{2}$ (1a) and [ $\left.\left\{\text { cis-Pt }\left(\mathbf{N H}_{3}\right)_{2} \mathbf{C I}\right\}_{2}(\mu-\mathbf{p z n})\right]\left(\mathbf{N O}_{3}\right)_{2}$ (1b). la. To the stirred DMF solution of [cis-Pt $\left.\left(\mathrm{NH}_{3}\right)_{2} \mathrm{Cl}(\mathrm{dmf})\right]\left(\mathrm{NO}_{3}\right)$ obtained as above, a solution of $86.5 \mathrm{mg}$ of pzn $(1.08 \mathrm{mmol})$ in $2 \mathrm{~mL}$ of DMF was added dropwise, and the solution was stirred at RT for $2 \mathrm{~h}$ in the dark. The solution was then rotary evaporated, and the residue was washed with diethyl ether. The crude product was dissolved in a minimal amount of $0.5 \mathrm{M} \mathrm{LiCl}$ aqueous solution, followed by adding excess of $\mathrm{MeOH}$. The solution was left overnight in the dark to yield a pale-yellow precipitate of $\mathbf{l a}$, which was washed with $\mathrm{MeOH}$ and diethyl ether and finally dried in air. Yield: $0.34 \mathrm{~g}(40 \%)$. Anal. Calcd for $\mathrm{Pt}_{2} \mathrm{C}_{4} \mathrm{H}_{16} \mathrm{~N}_{6^{-}}$ $\mathrm{Cl}_{4}$ : C, 7.06; H. 2.37; N, 12.36; Cl, 20.85. Found: C, 7.08; $\mathrm{H}$, 2.34; N, 11.95; Cl, 20.68.

1b.The same procedure as for 1a was carried out, but the crude product was recrystallized from $0.01 \mathrm{M}$ hydrochloric acid (without using $\mathrm{MeOH}$ ) resulting in pale yel low crystals of $\mathbf{1 b}$, and some of those were suitable for X-ray diffraction. Crystals were collected, washed with a small amount of $0.01 \mathrm{M}$ hydrochloric acid and dried in air. Yield: $0.29 \mathrm{~g}(32 \%)$. Anal. Calcd for $\mathrm{Pt}_{2} \mathrm{C}_{4} \mathrm{H}_{16} \mathrm{~N}_{8} \mathrm{Cl}_{2} \mathrm{O}_{6}$ : C, 6.55; $\mathrm{H}$. 2.20; N, 15.28; $\mathrm{Cl}, 9.67$. Found: C, 6.57; H, 2.22; N, 15.00; Cl, 9.95.

Preparation of $\left[\left\{\mathrm{Cis}-\mathrm{Pt}\left(\mathrm{NH}_{3}\right)_{2} \mathbf{C l}\right\}_{2}(\mu-\mathrm{pmn})\right] \mathrm{Cl}_{2}$ (2). To the stirred DMF solution of [cis-Pt $\left.\left(\mathrm{NH}_{3}\right)_{2} \mathrm{Cl}(\mathrm{dmf})\right]\left(\mathrm{NO}_{3}\right)$ obtained as above, $86.5 \mathrm{mg}$ of pmn $(1.08 \mathrm{mmol})$ in $2 \mathrm{~mL}$ of DMF was added dropwise, and the resulting solution was stirred at room temperature for $4 \mathrm{~h}$ in the dark. The solution was then rotary evaporated, and the residue was washed with diethyl ether. A crude product was dissolved in a minimal amount of $1 \mathrm{M}$ aqueous solution of $\mathrm{LiCl}$, then excess of $\mathrm{MeOH}$ was added, and the solution was left for a few hours in the dark to result in a white precipitate of $\mathbf{2}$. This precipitate was collected, washed with $\mathrm{MeOH}$ and diethyl ether, and dried in desiccator over $\mathrm{KOH}$. Yield: $0.30 \mathrm{~g}(35 \%)$. Anal. Calcd for $\mathrm{Pt}_{2} \mathrm{C}_{4} \mathrm{H}_{16} \mathrm{~N}_{6} \mathrm{Cl}_{4}$ : C, 7.06; H. 2.37; N, 12.36; Cl, 20.85. Found: C, 7.13; H, 2.52; N, 12.23; $\mathrm{Cl}, 20.71$.

Preparation of $\left[\left\{\mathrm{cis}-\mathrm{Pt}\left(\mathrm{NH}_{3}\right)_{2} \mathrm{Cl}\right\}_{2}(\mu-\mathrm{pdn})\right]\left(\mathrm{NO}_{3}\right)_{2}$ (3). To the stirred DMF solution of [cis-Pt $\left.\left(\mathrm{NH}_{3}\right)_{2} \mathrm{Cl}(\mathrm{dmf})\right]\left(\mathrm{NO}_{3}\right)$ obtained as above was added dropwise $87 \mathrm{mg}$ of pdn $(1.08 \mathrm{mmol})$ in $2 \mathrm{~mL}$ of DMF, and the resulting solution was stirred overnight in the dark at room temperature. Then it was rotary evaporated and extracted with $50 \mathrm{~mL}$ of $\mathrm{MeOH}$. The extract was filtered, rotary evaporated, and extracted again with 50 $\mathrm{mL}$ of $\mathrm{MeOH}$. The resulting extract was filtered, rotary evaporated, and washed with a small amount of EtOH to obtain a yellow microcrystalline powder of $\mathbf{3}$. As the powder was very hygroscopic, it was collected by centrifuging and finally dried in desiccator over $\mathrm{KOH}$. Yield: $0.23 \mathrm{~g}(25 \%)$. Anal. Calcd for $\mathrm{Pt}_{2} \mathrm{C}_{4} \mathrm{H}_{16} \mathrm{~N}_{8} \mathrm{Cl}_{2} \mathrm{O}_{6}$ : C, 6.55; H. 2.20; N, 15.28; Cl, 9.67. Found: $\mathrm{C}, 6.61 ; \mathrm{H}, 2.31 ; \mathrm{N}, 15.03 ; \mathrm{Cl}, 9.96 .{ }^{1} \mathrm{H} N M R\left(\mathrm{D}_{2} \mathrm{O}\right)$ : $\delta$ (pdn-resonance) $8.13(2 \mathrm{H}, \mathrm{t}), 9.62(2 \mathrm{H}, \mathrm{t}) .{ }^{195} \mathrm{Pt} \mathrm{NMR}\left(\mathrm{D}_{2} \mathrm{O}\right): \delta$ $-2251$.

X-ray Structural Determination. Single crystals of $\mathbf{1 b}$ as a nitrate salt were obtained by slow evaporation of $0.01 \mathrm{M}$ $\mathrm{HCl}$ aqueous solution. X-ray intensities were collected at 150(2) $\mathrm{K}$ on a Nonius KappaCCD diffractometer equipped with a
Table 9. Crystal Data for $\left[\mathrm{cis}-\left\{\mathrm{Pt}\left(\mathrm{NH}_{3}\right)_{2} \mathrm{Cl}\right\}_{2}(\mu-\mathrm{pzn})\right]\left(\mathrm{NO}_{3}\right)_{2}$ (1)

$\mathbf{1 b}$

$\begin{array}{ll}\text { chemical formula } & {\left[\mathrm{C}_{4} \mathrm{H}_{16} \mathrm{Cl}_{2} \mathrm{~N}_{6} \mathrm{Pt}_{2}\right]\left(\mathrm{NO}_{3}\right)_{2}} \\ \text { formula weight } & 733.31 \\ \text { crystal system } & \text { monoclinic } \\ \text { space group } & \mathrm{P} 2 \mathrm{y} / \mathrm{C}(\mathrm{No} .14) \\ \text { a }[\AA] & 7.6293(3) \\ \mathrm{b}[\AA] & 10.4762(7) \\ \mathrm{C}[\AA] & 11.9665(6) \\ \beta[\mathrm{deg}] & 126.387(5) \\ \mathrm{V}\left[\AA^{3}\right] & 769.96(9) \\ \mathrm{Z} & 2 \\ \rho_{\text {calcd }}\left[\mathrm{g} / \mathrm{cm}^{3}\right] & 3.163 \\ \mu\left[\mathrm{mm}{ }^{-1}\right] & 18.537 \\ \text { abs correction } & \text { analytical } \\ \text { transmission } & 0.04-0.20 \\ \text { crystal color } & \text { pale-yellow } \\ \left.\text { crystal size [mm }{ }^{3}\right] & 0.21 \times 0.30 \times 0.39 \\ \text { no. refl. measured } & 17426 \\ \text { no. unique refl. } & 1770 \\ \text { no. parameters } & 103 \\ \mathrm{R} 1 \text { (all refl) } & 0.0251 \\ \mathrm{R} 1 \text { (obs. refl) } & 0.0240 \\ \text { wR2 (all refl) } & 0.1156 \\ \text { wR2 (obs. refl) } & 0.1136\end{array}$

rotating anode and graphite monochromator (Mo K $\alpha$ radiation $\lambda=0.71073 \AA$ ). The structure was solved by automated Patterson techniques (DIRDIF 9737) and refined on $\mathrm{F}^{2}$ by fullmatrix least-squares techniques (SHELXL 9738). All structural drawings and geometrical calculations were performed with PLATON. ${ }^{39}$ Further details of the crystal structure determination for $\mathbf{1 b}$ are given in Table 9 , with standard data available from the Supporting I nformation.

NMR Measurements. All spectra were recorded on a 300 MHz Bruker DPX 300 spectrometer with a $5 \mathrm{~mm}$ multinucleus probe. The temperature was kept constant by a variable temperature unit. ${ }^{1} \mathrm{H}$ and ${ }^{195} \mathrm{Pt}$ chemical shifts were referenced to TSP and $\mathrm{Na}_{2} \mathrm{PtCl}_{6}(\delta=0 \mathrm{ppm})$, respectively. ${ }^{1} \mathrm{H}$ and ${ }^{195} \mathrm{Pt}$ NMR spectra of the separated products of GMP reaction were recorded in $\mathrm{D}_{2} \mathrm{O}$ at $298 \mathrm{~K}$ at $\mathrm{pD} 7.5$ adjusted with $0.1 \mathrm{M} \mathrm{DCl}$ and $0.1 \mathrm{M} \mathrm{NaOD}$.

Reactions with GMP in the NMR Tube. The reactions of the complexes, $\mathbf{1 a}, \mathbf{2}$, and $\mathbf{3}(4 \mathrm{mM})$ with 2 and 4 equiv of GMP (8 $\mathrm{mM}$ and $16 \mathrm{mM}$, respectively) were monitored over 8 $\mathrm{h}$ at $310 \mathrm{~K}$ by ${ }^{1} \mathrm{H}$ spectroscopy in $0.1 \mathrm{M} \mathrm{NaClO}_{4} \mathrm{D}_{2} \mathrm{O}$ solution ( $\mathrm{pD} \sim 7.5$ ) and $0.1 \mathrm{M} \mathrm{NaCl} \mathrm{D}_{2} \mathrm{O}$ solution ( $\mathrm{pD} \sim 7.5$ ). The reactions with GMP were quantified using relative integration values of $\mathrm{H} 8$ signals.

pH Titration. The pH titration was performed in $0.1 \mathrm{M}$ $\mathrm{NaClO}_{4} \mathrm{D}_{2} \mathrm{O}$ solution by adjustment of $\mathrm{pD}$ with 0.1 and $1 \mathrm{M}$ $\mathrm{DCl}, 0.1$ and $1 \mathrm{M} \mathrm{NaOD}$ without using a buffer. $\mathrm{pD}$ values were measured at 298K using a PHM 80 pH meter (Radiometer) before and after each ${ }^{1} \mathrm{H}$ NMR measurement.

Separation of the Products of the Reaction with GMP. The products resulting from the interaction between the azine bridged complexes and GMP were separated by Sephadex G-15 (Pharmacia) gel filtration column $\left(3 \varnothing \% 11 \mathrm{~cm}\right.$, solvent: $\mathrm{H}_{2} \mathrm{O}$, flow rate $0.75 \mathrm{~mL} / \mathrm{min}$, detection: UV (254 nm)) and subsequently lyophilized.

Mass Spectroscopic Measurements. Measurements were performed on a Finnigan MAT 900 equipped with an Electrospray Interface (ESI). Spectra were collected by constant infusion of the sample dissolved in water with $1 \%$ HOAC.

Cytotoxic Studies. In Vitro Cytotoxicity Assay in Human Tumor Cell Lines. In vitro cytotoxicity assays in human tumor cell lines were performed at the Dr. Daniel den Hoed Kliniek (Rotterdam Cancer Institute), Department of Medical Oncology (Rotterdam, The Netherlands). The seven well-characterized cell lines used were MCF 7 and EVSA-T (breast cancer), WIDR (colon cancer), I GROV (ovarian cancer), M19 (melanoma), A498 (renal cancer), and H226 (nonsmall cell lung cancer). All cell lines were maintained in a continuous logarithmic culture in RPMI 1640 medium with Hepes and 
phenol red. The medium was supplemented with $10 \%$ FCS, penicillin $100 \mathrm{IU} / \mathrm{mL}$, and streptomycin $100 \mu \mathrm{g} / \mathrm{mL}$. Cisplatin and the dinuclear platinum complexes were dissolved in water (1 mg/200 mL) and finally diluted in full medium. After $48 \mathrm{~h}$ preincubation of the tumor cells in 96-wel Is flatbottom microtiter plates, the solutions of the test compounds were added. The plates were incubated at $37{ }^{\circ} \mathrm{C}, 8.5 \% \mathrm{CO}_{2}$ for $120 \mathrm{~h}$. $\mathrm{IC}_{50}$ values were determined using the microculture sulforhodamine-B test (SRB). 40

In Vitro Cytotoxicity Assay in L 1210 Cell Lines Sensitive and Resistant to Cisplatin. The L 1210 murine leukemia cell line (J CRB 9026) was obtained from the Health Science Research Resources Bank (Osaka, J apan). The cisplatin-resistant L1210 (L 1210(cisPt)) was obtained by exposure of $\mathrm{L} 1210$ to $10 \mu \mathrm{M}$ cisplatin over a period of 3 months. L 1210 and L1210(cisPt) were cultured in suspension in RPMI 1640 medium (Sigma) supplemented with $10 \%$ heat-inactivated fetal calf serum and no antibiotics. The cells were grown at $37{ }^{\circ} \mathrm{C}$ in a $5 \% \mathrm{CO}_{2}$ humidified atmosphere.

Cytotoxicity was determined by MTT assay (MTT = 3-(4,5dimethylthiazol-2-yl)-2,5-diphenyl-2H-tetrazolium bromide). ${ }^{41}$ In brief, $200 \mu \mathrm{L}$ aliquots of a cell suspension containing $10^{5}$ cell/mL were pipetted into each well of the 96-well microtiter plate. The cells were treated for $48 \mathrm{~h}$ in the presence of various concentrations of platinum complexes. Following exposure to the drugs, $10 \mu \mathrm{l}$ of a $50 \mathrm{mg} / \mathrm{mL}$ MTT solution was added to each well and the plate was left at $37{ }^{\circ} \mathrm{C}$ for $4 \mathrm{~h}$. Then the culture media were removed, and the plate was washed with PBS (phosphate buffer in saline). The precipitated dye was solubilized by adding $200 \mu \mathrm{l}$ of 2-propanol. The absorbance was measured using a microplate reader at $570 \mathrm{~nm}$. The I $\mathrm{C}_{50}$ value was defined as the drug concentration that reduced the absorbance by $50 \%$, compared to the drug-free control.

Acknowledgment. The authors are indebted to The Kidani Memorial Trust for a fellowship to Seiji Komeda. Also travel support and sponsorship by COST Action D20/0001/00 (biocoordination chemistry) is kindly acknowledged. The authors are grateful to J ohnson \& Matthey (Reading, UK) for their generous loan of $\mathrm{K}_{2^{-}}$ $\mathrm{PtCl}_{4}$ and to PCN/Pharmachemie BV (Haarlem, NL) for performing cytotoxicity tests. This research has been financially supported in part (M.L. and A.L.S.) by the Council for Chemical Science of The Netherlands Organization for Scientific Research (CW-NWO).

Supporting Information Available: Crystallographic data (atomic coordinates, bond lengths, angles, torsion angles, displacement parameters) for compound $\mathbf{1 b}$. This material is available free of charge via the Internet at http://pubs.acs.org.

\section{References}

(1) Rosenberg, B.; Van Camp, L.; Krigas, T. Inhibition of cell division in Escherichia coli by electrolysis products from a platinum electrode. Nature 1965, 205, 698-699.

(2) Rosenberg, B.; Van Camp, L.; Trosko, J. E.; Mansour, V. H Platinum compounds: a new class of potent antitumour agents. Nature 1969, 222, 385-386.

(3) Giaccone, G. Clinical perspectives on platinum resistance. Drugs 2000, 59, 9-17.

(4) Von Hoff, D. D.; Schilsky, R.; Reichert, C. M. Toxic effects of cis-dichlorodiammineplatinum(II) in man. Cancer Treat. Rep. 1979, 63, 1527-1531.

(5) McMillan, T. J .; Stephens, T. C.; Steel, G. G. Development of drug resistance in a murine mammary tumour. Br. J . Cancer, 1985, 52, 823-32.

(6) Roberts, J . J .; Thomson, A. J. The mechanism of action of antitumor platinum compounds. Prog. Nud. Acid Res. Mol. Biol. 1979, 22, 71-133.

(7) Yang, D.-Z.; Van Boom, S. S. G. E.; Reedijk, J .; Van Boom, J H.; Wang, A. H.-J . Structure and isomerization of an intrastrand cisplatin-cross-linked octamer DNA duplex by NMR analysis. Biochemistry 1995, 34, 12912-12920.

(8) Reedijk, J. Improved understanding in platinum antitumour chemistry. Chem. Commun. 1996, 801-806.
(9) Gelasco, A.; Lippard, S. J . NMR solution structure of a DNA dodecamer duplex containing a cis-diammineplatinum(II) d(GpG) intrastrand cross-link, the major adduct of the anticancer drug cisplatin. Biochemistry 1998, 37, 9230-9239.

(10) Takahara, P. M.; Rosenzweig, A. C.; Frederick, C. A.; Lippard, S. J . Crystal-structure of double-stranded DNA containing the major adduct of the anticancer drug cisplatin. Nature 1995, 377, 649-652.

(11) Marzilli, L. G.; Saad, J . S.; Kuklenyik, Z.; Keating, K. A.; Xu, Y $H$. Relationship of solution and protein-bound structures of DNA duplexes with the major intrastrand cross-link lesions formed on cisplatin binding to DNA. J . Am. Chem. Soc. 2001, 123, 27642770.

(12) Andrews, P. A.; Howell, S. B. Cellular pharmacology of cisplatin - Perspectives on mechanisms of acquired resistance. Cancer Cells 1990, 2, 35-43.

(13) De Graeff, A.; Slebos, R. J. C.; Rodenhuis, S. Resistance to cisplatin and analogues: mechanisms and potential clinica implications. Cancer Chemother. Pharmacol. 1988, 22, 325-332.

(14) Kelley, S. L.; Rozencweig, M. Resistance to platinum compounds: mechanisms and beyond. Eur. J . Cancer Clin. Oncol. 1989, 25, 1135-1140.

(15) Hospers, G. A. P.; Mulder, N. H.; de Vries, E. G. E. Mechanisms of cellular resistance to cisplatin. Med. Oncol. Tumor Pharmacother. 1988, 5, 145-151.

(16) Ishikawa, T.; Ali-Osman, F. Glutathione-associated cis-diamminedichloroplatinum(II) metabolism and ATP-dependent efflux from leukemia-cells - Molecular characterization of glutathioneplatinum complex and its biological significance. J. Biol. Chem. 1993, 268, 20116-20125.

(17) Wang, W.; Ballatori, N. Endogenous glutathione conjugates: Occurrence and biological functions. Pharmacol. Rev. 1998, 50 335-355.

(18) Kelley S. I.; Basu, A.; Teicher, B. A.; Hacker, M. P.; Hamer, D. H.; Lazo, J . S. Overexpression of metallothionein confers resistance to anticancer drugs. Science 1988, 241, 1813-1815.

(19) Kasahara, K.; Fujiwara, Y.; Ohmori, T.; Sugimoto, Y.; Komiyama, K.; Matsuda, T.; Sanjo, N. Metallothionein content correlates with the sensitivity of human small-cell lung-cancer cell-lines to cisplatin. Cancer Res. 1991, 51, 3237-3242.

(20) Basu, A.; Lazo, J. S. Suppression of dexamethasone-induced metallothionein expression and cis-diamminedichloriplatinum(II) resistance by V-mos. Cancer Res. 1991, 51, 893-896.

(21) Eastman, A.; Schulte, N. Enhanced DNA repair as a mechanism of resistance to cis-diamminedichloroplatinum(II). Biochemistry 1988, 27, 4730-4734.

(22) Komeda, S.; Lutz, M.; Spek, A. L.; Chikuma, M.; Reedijk, J. New antitumor-active azole-bridged dinuclear platinum(II) complexes: Synthesis, characterization, crystal structures, and cytotoxic studies. I norg. Chem. 2000, 39, 4230-4236.

(23) Komeda, S.; Lutz, M.; Spek, A. L.; Yamanaka, Y.; Sato, T Chikuma, M.; Reedijk, J . A novel isomerization on interaction of antitumor-active azole-bridged dinuclear platinum(II) complexes with 9-ethylguanine. Platinum(II) atom migration from N2 to N3 on 1,2,3-triazole. J . Am. Chem. Soc. 2002, 124, 47384746.

(24) Komeda, S.; Ohishi, H.; Yamane, H.; Harikawa, M.; Sakaguchi, K.; Chikuma, M. An NMR study and crystal structure of [ cis$\left.\left.\mathrm{Pt}\left(\mathrm{NH}_{3}\right)_{2}\left(9 \mathrm{EtG}-\kappa \mathrm{N}^{7}\right)\right\}_{2}-(u-\mathrm{pz})\right]\left[\mathrm{NO}_{3}\right]_{3}(9 \mathrm{EtG}=9$-ethylguanine) as a model compound for the 1,2-intrastrand GG cross-link. J . Chem. Soc., Dalton Trans. 1999, 2959-2962.

(25) Teuben, J .-M.; Elizondo-Riojas, M.-A.; Komeda, S.; Reedijk, J . Kozelka, J . to be submitted, 2002.

(26) Appleton, T. G.; Hall, J. R.; Ralph, S. F. ${ }^{15} \mathrm{~N}$ and ${ }^{195} \mathrm{Pt}$ NMR spectra of platinum ammine complexes: trans- and cis-influence series based on ${ }^{195} \mathrm{Pt}-15 \mathrm{~N}$ coupling constants and ${ }^{15} \mathrm{~N}$ chemical shifts. Inorg. Chem. 1985, 24, 4685-4693.

(27) Bancroft, D. P.; Lepre, C. A.; Lippard, S. J . 195Pt NMR kinetic and mechanistic studies of cis-diamminedichloriplatinum and trans-diamminedichloriplatinum(II) binding to DNA. J. Am Chem. Soc. 1990, 112, 6860-6871.

(28) O'Halloran, T. V.; Lippard, S. J . Isomerization of binuclear amidate-bridged platinum(II) amine complexes: a $195 \mathrm{Pt}$ NMR investigation. Inorg. Chem., 1989, 28, 1289-1295.

(29) Marcelis, A. T. M.; van Kralingen, C. G.; Reedijk, J. The interactions of cis- and trans-diammineplatinum compounds with 5'-guanosine monophosphate and 5'-deoxyguanosine monophosphate. A proton NMR investigation. J. Inorg. Biochem. 1980, 13, 213-222

(30) Fanchiang, Y.-T. Reaction intermediates of cis-diammineaqua(hydroxo)platinum(II) with guanisine 5'-monophosphate characterized by proton nuclear magnetic resonance spectroscopy. J . Chem. Soc., Dalton Trans. 1986, 135-140.

(31) Mellish, K. J .; Qu, Y.; Scarsdale, N.; Farrell, N. Effect of geometric isomerism in dinuclear platinum antitumour complexes on the rate of formation and structure of intrastrand adducts with oligonucleotides. Nud. Acid Res. 1997, 25, 12651271. 
(32) Clore, G. M.; Gronenborn, A. M. Kinetic and structural studies on the intermediates formed in the reactions of $5^{\prime}$-adenosine monophosphate and 5'-guanosine monophosphate with cisdichlorodiammineplatinum(II) using ${ }^{1} \mathrm{H}$ and ${ }^{195} \mathrm{Pt}$ magnetic resonance spectroscopy. J . Am. Chem. Soc. 1982, 104, 1369 1375.

(33) Berners-Price, S. J .; Kuchel, P. W. J . Reaction of cis-[PtCl $\left.\left.\mathrm{PHH}_{3}\right)_{2}\right]$ and trans- $\left[\mathrm{PtCl}_{2}\left(\mathrm{NH}_{3}\right)_{2}\right]$ with reduced glutathione studied by ${ }^{1} \mathrm{H}$ ${ }^{1} \mathrm{H},{ }^{13} \mathrm{C}-1 \mathrm{H},{ }^{195} \mathrm{Pt}-1 \mathrm{H}$ and ${ }^{15} \mathrm{~N}-1 \mathrm{H}$ DEPT NMR. Inorg. Biochem 1990, 38, 305-326.

(34) Dijt, F. G.; Canters, G. W.; den Hartog, J . H. J .; Marcelis, A. T. M.; Reedijk, J. Reaction products of cis-diammineplatinum(II) compounds with $5^{\prime}$-guanosine monophosphate characterized by high-frequency proton NMR. J. Am. Chem. Soc. 1984, 106, 3644-3647.

(35) Chu, G. Y. H.; Mansy, S.; Duncan, R. E.; Tobias, R. S. Heavy metal nucleotide interactions. II. Stereochemical and electronic effects in the electrophilic attack of cis- and trans-diammine platinum(II) on 5'-guanosine monophosphate and polyguanylate in aqueous solution. J. Am. Chem. Soc. 1978, 100, 593-606.
(36) Dhara, S. C. A rapid method for the synthesis of cis-[Pt $\left(\mathrm{NH}_{3}\right)_{2-}$ $\mathrm{Cl}_{2}$ ]. Indian J . Chem. 1970, 8, 193-194.

(37) Beurskens, P. T.; Admiraal, G.; Beurskens, G.; Bosman, W. P. Garcia-Granda, S.; Gould, R. O.; Smits, J. M. M.; Smykalla, C. The DIRDIF 97 program system; Technical Report of the Crystallography Laboratory, University of Nijmegen: Nijmegen, 1997.

(38) Sheldrick, G. M. SHELXL 97, Program for Crystal Structure Refinement; University of Göttingen, Göttingen, Germany, 1997.

(39) Spek, A. L. PLATON - a multipurpose crystallographic tool, Utrecht University, The Netherlands, 2001.

(40) Keepers, Y. P.; Pizao, P. E.; Peters, G. J .; Van Ark-Otte, J Winograd, B.; Pinedo, H. M. Comparison of the sulforhodamine-B protein and tetrazolium (MTT) assays for in vitro chemosensitivity testing. Eur. J . Cancer 1991, 27, 897-900.

(41) Mossmann, T. Rapid colorimetric assay for cellular growth and survival: application to proliferation and cytotoxicity assays. J I mmunol. Methods 1983, 83, 55-63.

J M020004+ 